\title{
Z ZNACZENIE KWASU FOLIOWEGO W DIECIE OSÓB STARSZYCH. ZASADNOŚĆ SUPLEMENTACJI ŻYWNOŚCI
}

\section{THE IMPORTANCE OF FOLIC ACID IN THE DIET OF OLDER PEOPLE. THE VALIDITY OF FOOD SUPPLEMENTATION}

\author{
Marzanna Mziray ${ }^{1}$, Magdalena Siepsiak², Regina Żuralska' ${ }^{1}$ Przemysław Domagała ${ }^{3}$ \\ ${ }^{1}$ Zakład Pielęgniarstwa Społecznego i Promocji Zdrowia \\ Gdański Uniwersytet Medyczny \\ ${ }^{2}$ Katedra i Klinika Gastroenterologii i Hepatologii \\ Gdański Uniwersytet Medyczny \\ Uniwersyteckie Centrum Kliniczne w Gdańsku \\ ${ }^{3}$ Zakład Zarządzania w Pielęgniarstwie \\ Gdański Uniwersytet Medyczny
}

DOI: https://doi.org/10.20883/pielpol.2017.39

\begin{abstract}
STRESZCZENIE
Kwas foliowy (folacyna, folan, witamina $B_{9}$ ) jest witaminą o istotnym znaczeniu dla właściwego funkcjonowania organizmu człowieka. Foliany znajdują się w produktach spożywczych pochodzenia roślinnego i pochodzenia zwierzęcego. Wśród produktów roślinnych wysoką ich zawartością cechują się surowe i krótko gotowane zielone warzywa liściaste. Spośród produktów pochodzenia zwierzęcego jego wysoką ilość stwierdza się w podrobach. Niskie spożycie kwasu foliowego i w efekcie zbyt niski poziom tej witaminy w organizmie może być podłożem licznych schorzeń. Osoby starsze narażone są na wystąpienie niedoborów folianów nie tylko z powodu błędów w sposobie żywienia. Ich przyczyną może być osłabione wchłanianie czy czynniki związane ze stylem życia. Najgroźniejsze następstwa zdrowotne dla starszych osób łączą się z wysokim stężeniem homocysteiny we krwi, co jest czynnikiem wywołującym zaburzenia funkcji poznawczych, choroby sercowo-naczyniowe, a także nowotwory. Dostarczenie zgodnej z zapotrzebowaniem organizmu ilości folianu w diecie jest problematyczne, ponieważ długotrwałe przechowywanie produktów spożywczych, które są ich naturalnym źródłem, oraz ich obróbka technologiczna wpływają negatywnie na ilość i przyswajalność tej witaminy. Konieczne staje się więc stosowanie suplementacji.
\end{abstract}

SŁOWA KLUCZOWE: kwas foliowy, osoby starsze, suplementacja żywności.

\section{Wprowadzenie}

Kwas foliowy odkryty został na przełomie lat 30. i 40. XX w. Inspiracjądo poszukiwańbyło stwierdzenie,żewdrożdżach znajduje się substancja o właściwościach terapeutycznych. Angielska lekarka Lucy Wills w latach 30 zauważyła, że anemię występującą u indyjskich kobiet można leczyć stosując wyciąg z drożdży. Doświadczenie przeprowa-

\begin{abstract}
Folic acid (folacin, folate, vitamin $B_{9}$ ) is a vital vitamin for the proper functioning of the human body. Folates are found in foodstuffs of plant and animal origin. Among the plant products their high content can be found in raw and short cooked green leafy vegetables. Among the products of animal origin its high amount is found in offal. Low intake of folic acid in the diet and, as a result, too low a level of this vitamin in the body can be a substrate for many diseases. Elderly people are exposed to folate deficiencies not only because of dietary errors. The cause may be reduced absorption or lifestyle factors. The most serious health consequences for older people are associated with high levels of homocysteine in blood, which is the reason for cognitive impairment, cardiovascular disease, and cancer. Providing the body's required amount of folate in the diet is problematic since the long-term storage of food products that are its natural source and their technological processing affect negatively the amount and bioavailability of this vitamin. It is therefore necessary to use supplementation.
\end{abstract}

KEYWORDS: folic acid, the elderly, food supplementation.

dzone z udziałem małp udowodniło terapeutyczne działanie tego wyciągu, a związek leczący anemię nazwano „Wills factor". Witaminę $B_{6}$ po raz pierwszy wyizolowano w 1941 r. z liści szpinaku, co zostało uwiecznione w jej określeniu (łac. folium - liść). Po pięciu latach grupa amerykańskich chemików najpierw pozyskała formę krystaliczną, a później zsyntetyzowała kwas foliowy [1]. 
Pod względem chemicznym kwas foliowy, zwany też witaminą $B_{9}$ bądź $B_{11}$, zbudowany jest z zasady pterydynowej (6-metylopteryny), kwasu p-aminobenzoesowego (PABA) i kwasu glutaminowego [2]. Kwas foliowy i jego pochodne to grupa folianów, które różnią się pomiędzy sobą utlenowaniem pierścienia pterydyny oraz liczbą reszt kwasu glutaminowego, od 1 do 11. Związki te wykazują porównywalną aktywność biologiczną, ale kwas foliowy jest związkiem cechującym się największą stabilnością i najlepszą przyswajalnością [3]. Organizm człowieka, poza znikomymi ilościami powstającymi przy udziale mikroflory jelitowej, nie jest zdolny do wytwarzania tej witaminy, w związku z czym musi być ona dostarczana z pokarmem [2].

Foliany zawarte są zarówno w roślinnych, jak i zwierzęcych produktach spożywczych. Wśród produktów pochodzenia roślinnego największe ilości folianów mają zielone warzywa liściaste surowe i krótko gotowane, a wśród produktów pochodzenia zwierzęcego podroby. W organizmie człowieka znajdują się zapasy kwasu foliowego w ilości około 5-10 mg, z czego połowa zmagazynowana jest w wątrobie [2, 4].

Kwas foliowy jest konieczny do prawidłowego rozwoju i funkcjonowania komórek układu krwiotwórczego i nerwowego oraz tkanek zbudowanych z komórek o intensywnych podziałach (nabłonek przewodu pokarmowego, tkanki płodu) [5, 6, 7]. Niedostateczna podaż kwasu foliowego z dietą i w efekcie niski poziom tego związku w organizmie może być czynnikiem ryzyka licznych chorób. W grupie osób starszych najpoważniejsze następstwa zdrowotne połączone są z wysokim stężeniem homocysteiny we krwi, stanowiącym przyczynę zaburzeń funkcji poznawczych, chorób sercowo-naczyniowych oraz niektórych nowotworów. Osoby starsze narażone są na wystąpienie niedoborów folianów nie tylko z powodu błędów w sposobie żywienia. Przyczyną ich może być osłabione wchłanianie czy czynniki związane ze stylem życia (palenie papierosów, picie alkoholu, wielolekowość) [8].

W wielu krajach na świecie, w tym także w Polsce, dostrzega się wydłużanie okresu życia, a co za tym idzie wzrost liczby osób w wieku podeszłym. Skutkuje to wzrostem zainteresowania wpływem sposobu żywienia na utrzymanie zdrowia i jakość życia osób starszych. Opierając się na obecnych danych o prozdrowotnym działaniu kwasu foliowego na organizm człowieka , można stwierdzić, że suplementacja żywności kwasem foliowym wydaje się całkowicie uzasadniona, jak również jest najlepszym sposobem wyrównywania jego niedoborów [1, 2, 8].

Celem pracy była analiza dostępnego piśmiennictwa na temat znaczenia kwasu foliowego dla zdrowia, charakterystyka najczęstszych następstw zdrowotnych niedoboru folianu u osób starszych, a także przedstawienie korzyści wynikających z uzupełniania jego deficytu.

\section{Zawartość folianów w żywności}

Foliany znajdują się w produktach spożywczych pochodzenia roślinnego i pochodzenia zwierzęcego. Wśród produktów roślinnych wysoką ich zawartością cechują się surowe i krótko gotowane zielone warzywa liściaste, takie jak: brukselka, brokuły, szpinak, szparagi, kapusta włoska, korzeń i liść pietruszki czy sałata. W nasionach roślin strączkowych, takich jak: groch, fasola i soja, znajdują się duże ilości folianów. W wymienionych produktach ich zawartość sięga 150-200 g/100 g. Drożdże, kiełki pszenicy i pełne ziarna zbóż mają w swoim składzie foliany w znacznych ilościach. Bogatym ich źródłem są owoce i warzywa, mające w swoim składzie także witaminę C lub $\beta$-karoten - papryka, jarmuż, pietruszka, maliny, kiwi oraz pomarańcze. Cenne źródło kwasu foliowego to także orzechy - jego zawartość w orzechach arachidowych wynosi do $110 \mu \mathrm{g} / 100 \mathrm{~g}$ i od $66 \mu \mathrm{g} / 100 \mathrm{~g}$ w przypadku orzechów włoskich [1, 2, 9].

Wśród produktów pochodzenia zwierzęcego bogatym źródłem folianów są podroby, głównie wątroba (200-580 $\mu \mathrm{g} / 100 \mathrm{~g})$. Niewielką ilość kwasu foliowego zawierają natomiast wędliny. Niska zawartość tej witaminy jest także w mleku, wynosi ok. $5 \mu \mathrm{g} / 100 \mathrm{~g}$. Napoje mleczne fermentowane, takie jak jogurt czy maślanka, mają w swoim składzie niewielkie ilości kwasu foliowego (7-10 $\mu \mathrm{g} / 100 \mathrm{~g})$, będącego metabolitem bakterii kwasu mlekowego. Od 10 do $40 \mu \mathrm{g} / 100 \mathrm{~g}$ tych związków zawierają sery dojrzewające twarde, a ok. $30 \mu \mathrm{g} / 100$ g twarogi. Cenniejszym źródłem są sery dojrzewające miękkie (camembert, brie), zawierające 60-100 $\mu \mathrm{g} / 100$ g folianów. Jaja (zwłaszcza żółtka) cechują się także dużą zawartością witaminy $\mathrm{B}_{9}-65 \mu \mathrm{g} / 100 \mathrm{~g}$. Łosoś, mający w swoim składzie $26 \mu \mathrm{g} / 100 \mathrm{~g}$ kwasu foliowego, jest spośród ryb najbogatszym jego źródłem [1, 2, 4, 9]

W wymienionych produktach spożywczych foliany występują przede wszystkim w postaci zredukowanych wieloglutaminowych pochodnych kwasu foliowego, tetrahydrofolianowych lub dihydrofolianowych [1, 2, 4].

\section{Biodostępność folianów}

Biodostępność kwasu foliowego, czyli ilość i szybkość, z jaką ten składnik odżywczy jest wchłaniany w przewodzie pokarmowym, uwarunkowana jest wieloma czynnikami, takimi jak postać folianów w produktach spożywanych, rodzaj tych produktów (naturalne, syntetyczne), sposób ich technologicznej obróbki, jak również od spożycia alkoholu, palenia papierosów, zażywanych leków czy stanów zapalnych układu pokarmowego [4]. W produktach spożywczych kwas foliowy 
występuje głównie w postaci poliglutaminianów. Aby całkowicie mógł być wchłaniany w jelicie, musi zostać zhydrolizowany przez enzym karboksypeptydazę II glutiaminianu (GCP2) do monoglutaminianów [10]. Za pośrednictwem krwi w tej postaci dociera do tkanek i wątroby, gdzie jest składowany ponownie w postaci wieloglutaminowych związków [2]. Biodostępność folianów zależy od szeregu czynników, między innymi od pH, od którego zależy aktywność GCP2. Dla tego enzymu optymalne $\mathrm{pH}$ zawiera się w granicach 6-7, natomiast w przypadku spożycia folianów z produktem spożywczym obniżającym pH, jego aktywność osłabia się i mniej folianów zostaje wchłoniętych do krwi. Na aktywność GCP2 inhibitorowy efekt wywierają ponadto jony kwasów organicznych, etanol i niektóre leki [10]. Prawidłowe i efektywne wykorzystanie folianów przez organizm umożliwia spożywanie też innych witamin i biopierwiastków, takich jak witamina $C$, witamina $B_{12}$, żelazo i cynk [11]. Udowodniono, że przeciętne spożycie folianów nie pozwala na całkowite pokrycie zapotrzebowania na tę witaminę. Jej częste subkliniczne niedobory są rezultatem małej biodostępności naturalnie występujących w pożywieniu folianów. Większą zdecydowanie biodostępnością charakteryzuje się kwas foliowy syntetyczny (stopień przyswajalności na czczo określa się na $100 \%$ przyjmowany w postaci suplementów lub obecny w fortyfikowanych produktach spożywczych $[10,11]$.

\section{Spożycie folianów przez osoby starsze}

Zalecane normy spożycia folianów dla ludności w Polsce są porównywalne do norm większości krajów europejskich

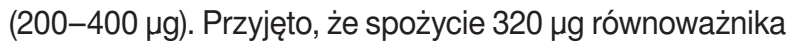
folianów na dobę (poziom EAR - średnie zapotrzebowanie grupy) gwarantuje występowanie właściwego stężenia kwasu foliowego w erytrocytach oraz homocysteiny w surowicy krwi u osób dorosłych [12]. 6,8-27 ng/ml - to zalecana ilość folianów w surowicy, natomiast 30-krotnie więcej witaminy $B_{9}$ może być w erytrocytach [13].

Z badań przeprowadzonych w Polsce wynika, że średnie spożycie omawianej witaminy wśród starszych osób ( $\geqslant 60$ r.ż.) zawierało się w zakresie 133-284 $\mu \mathrm{g}$ dziennie, co stanowiło 41-89\% normy. Najniższe spożycie stwierdzono w grupie osób w wieku 75-80 lat, gdzie u $6,5 \%$ badanych zauważono niskie stężenie kwasu foliowego w surowicy krwi (14 $\mathrm{mmol} / \mathrm{l})$, a ponadto u $40 \%$ wykazano podwyższony poziom homocysteiny we krwi (> $14 \mu \mathrm{mol} / \mathrm{l})[14]$.

Duże ryzyko niedoboru kwasu foliowego wykazali Wierzbicka i wsp. w badaniach stanu odżywienia starszych mieszkańców Warszawy. Niższe od 6,8 ng/ $\mathrm{ml}$ stężenie folianów we krwi było o u $7 \%$ kobiet i $25 \%$ mężczyzn [15].
Poważne niedobory folianów u osób między 60 a 96 r.ż. potwierdziły badania Stawarskiej i wsp. [16]. Przebadane kobiety zrealizowały zapotrzebowanie na foliany w ilości 51,8\% i 60,3\%, natomiast mężczyźni w ilości 56\% i 71,7\%.

Obserwując sytuację żywieniową wśród starszych osób w 11 krajach Europy, najwyższe spożycie folianów (311 $\mu \mathrm{g} /$ osobę/dobę) zauważono w Hiszpanii w grupie mężczyzn, zaś najniższe (166 $\mu \mathrm{g} / \mathrm{osobę/dobę)} \mathrm{w} \mathrm{Austrii}$ w grupie kobiet powyżej 85 r.ż. Wysokie średnie spożycie (>350 $\mu \mathrm{g} /$ osobę/dobę) wykazano w badaniach wykonanych w Wielkiej Brytanii, na poziomie średnim (250-350 $\mu \mathrm{g} /$ osobę/ dobę) spożycie folianów zaobserwowano w Finlandii, Irlandii, Francji, Niemczech, Hiszpanii i Włoszech, natomiast niskie spożycie $(<250 \mu \mathrm{g} /$ osobę/dobę) stwierdzono w Holandii, Danii, Norwegii, Szwecji i w jednym badaniu hiszpańskim [14, 17].

Obserwacja badań przeprowadzonych w Polsce dowiodła, że podstawowym naturalnym źródłem omawianej witaminy w diecie dorosłych osób były przede wszystkim warzywa oraz pieczywo [14-18]. Podobnie analiza krajowych badań budżetów gospodarstw domowych przeprowadzonych w 2007 roku przez Główny Urząd Statystyczny wykazała, iż głównym źródłem folianów były także warzywa (35\%) i produkty zbożowe (32\%) [19].

\section{Skutki niedoboru folianów w diecie osób starszych}

Foliany to składniki odżywcze pełniące istotną rolę w żywieniu osób starszych. Błędy w codziennej diecie, upośledzone wchłanianie, czynniki związane ze stylem życia, takie jak palenie papierosów, picie alkoholu, jak również powszechna w starszym wieku wielolekowość, to główne przyczyny występowania deficytów folianów w populacji osób starszych. Niedobór folianów skutkuje licznymi chorobami dotykającymi osoby starsze, jak choroby serca i naczyń krwionośnych, choroby układu nerwowego, nowotwory, choroby nerek czy reumatoidalne zapalenie stawów [8]. Deficyt folianów w organizmie powoduje wzrost stężenia homocysteiny we krwi. Hiperhomocysteinemia częściej rozpoznawana jest u osób w wieku starszym oraz częściej u mężczyzn niż u kobiet [8-10]. Wyniki amerykańskich badań wskazują, że hiperhomocysteinemia może występować u 5-10\% całej populacji i u 30-40\% populacji osób starszych [8, 20]. Zwiększone stężenie homocysteiny we krwi stwierdzono również u 40\% badanych osób starszych mieszkających w rejonie Warszawy [9].

Wiele badań zwraca uwagę na przyczynowy związek między hiperhomocysteinemią a wzmożeniem procesów miażdżycowych, potęgowaniem ryzyka niedokrwiennej 
choroby serca i zakrzepicy naczyń obwodowych, a także udaru mózgu. Homocysteina wykazuje właściwości cytotoksyczne, tj. uszkadza komórki śródbłonka naczyń krwionośnych, powoduje degradację elastyny w błonie wewnętrznej, dynamizuje proces włóknienia i wapnienia. Tworząc związki z tlenkiem azotu, aminokwas ten minimalizuje jego ochronne działanie oraz ujawnia zdolność do peroksydacji LDL. Ma też działanie prozakrzepowe, wpływając na aktywność co najmniej kilku czynników krzepnięcia [8, 21-23].

Udowodniono, że u większości osób spożycie folianów w ilości mniejszej od 200-250 ug/dzień z żywnością i suplementami jest często związane z hiperhomocysteinemią, podczas gdy spożycie w zakresie 300-400 $\mu \mathrm{g} /$ dzień jest dostateczne do normalizacji poziomu tego aminokwasu we krwi [24].

Przeprowadzone dotychczas badania udowodniły istnienie związku między folianami a chorobami nowotworowymi. Wynika on z faktu, iż foliany odgrywają ważną rolę w syntezie nukleotydów, metylacji DNA, RNA, białek i fosfolipidów. Przypuszczalnie proces nowotworowy jest łączony z przerwaniem integralności DNA na skutek m.in. wbudowania uracylu do cząsteczki kwasu nukleinowego. Obniżenie sprawności mechanizmów naprawczych, być może związane ze zmianą proporcji w puli dostępnych dezoksyrybonukleotydów oraz z zaburzeniami metylacji DNA, wykazano także w badaniach doświadczalnych na hodowlach komórkowych, na zwierzętach i na ludziach [25]. Hipometylację DNA limfocytów odnotowano m.in. u kobiet powyżej 63 roku życia, którym przez 7 tygodni podawano dietę ubogą w foliany [26]. Badania z udziałem szczurów udowodniły, że odpowiednie spożycie folianów może zminimalizować ryzyko wystąpienia nowotworów powiązanych ze starzeniem się organizmu poprzez blokowanie zmian w ekspresji niektórych genów [27].

$\mathrm{Na}$ zwiększenie ryzyka nowotworów mózgu, przełyku, płuc, piersi, trzustki, jelita grubego i szyjki macicy przy deficytach folianów w organizmie wskazuje wiele badań epidemiologicznych. Najbardziej przekonujące dane dotyczą jednak nowotworów jelita grubego. Brakuje natomiast udokumentowanych danych udowadniających korzystny wpływ dużych dawek folianów u osób obciążonych ryzykiem chorób nowotworowych [28, 29].

Istotny związek między podażą folianów a występowaniem stanów przedrakowych (gruczolaki) i nowotworów jelita grubego udowodniły wyniki kilku prospektywnych badań kohortowych [30-32]. U osób dostarczających z dietą więcej niż $700 \mu \mathrm{g}$ folianów dziennie ryzyko gruczolaków jelita grubego było o 30-40\% mniejsze w stosunku do osób przyjmujących mniej niż $240 \mu \mathrm{g} / \mathrm{dzień}$ [30]. Po 14 latach monitoringu w ramach Nurses' Health Study udowodniono, że przy dostarczaniu co najmniej
$400 \mu \mathrm{g}$ folianów w diecie w ciągu dnia, ryzyko nowotworów jelita grubego było o $31 \%$ mniejsze niż przy podaży poniżej $200 \mu \mathrm{g}$ dziennie.

Badania kohortowe przeprowadzone w Kanadzie [33], wśród starszych mieszkanek stanu lowa [34] oraz wśród pielęgniarek [35] pokazały, że zwiększenie podaży folianów w diecie u kobiet, które przyjmują powyżej $14 \mathrm{~g}$ alkoholu dziennie, zmniejsza ryzyko wystąpienia nowotworu piersi.

Wiele danych sugeruje też znaczenie folianów lub homocysteiny w utrzymaniu funkcji poznawczych, demencji i chorobie Alzheimera [27]. Wśród badanych w wieku powyżej 65 r.ż. bez klinicznych objawów funkcji poznawczych, osoby osiągające lepsze wyniki w teście sprawności umysłowej (Mini-Mental State Examination) miały istotnie niższe stężenie homocysteiny we krwi [24]. Zbliżone korelacje dla niektórych funkcji poznawczych pozyskano także u badanych w ramach Epidemiology of Vascular Ageing we Francji [9], a także w ramach Maastricht Aging Study w Holandii [33].

Badania wśród uczestniczek Nun Study w USA wykazały, iż poziom kwasu foliowego w surowicy krwi był mocno negatywnie skorelowany $z$ atrofią kory mózgowej nie tylko u kobiet $z$ chorobą Alzheimera ( $r=-0,8, p=0,0006)$, ale także u wszystkich uczestniczek badania $(r=-0,40$, $p=0,03$ ). Należy zaznaczyć, że nie potwierdzono występowania takiego związku dla 18 innych odżywczych składników [31].

Pożądany poziom folianów w surowicy oraz redukcję objawów klinicznych ich niedoboru można uzyskać, stosując doustną i parenteralną terapię substytucyjną $[11,12]$ oraz suplementację żywności witaminą $B_{12}$ [13].

Odpowiednia modyfikacja diety poprzez wprowadzenie produktów bogatych w foliany, jak surowe zielone warzywa, pomarańcze, produkty z pełnego ziarna, strączkowe [36], produktów wzbogaconych kwasem foliowym [37], a także suplementacja, są efektywnymi sposobami obniżenia poziomu homocysteiny we krwi [12, 34, 35].

W badaniach kohortowych w ramach Framingham Study monitorowaniem objęto 1092 osoby w wieku 76 lat bez objawów klinicznych demencji. Na przestrzeni 8 lat u 111 osób potwierdzono demencję, w tym u 89 osób z rozpoznaną chorobą Alzheimera. Wzrost poziomu homocysteiny we krwi o $5 \mu \mathrm{mol} / /$ potęgował ryzyko wystąpienia tych chorób, przy czym ryzyko zwiększało się dwukrotnie, gdy stężenie homocysteiny wynosiło powyżej 14 moli/l i było niezależne od płci, wieku, poziomu witamin we krwi i innych czynników domyślnie związanych z ich powstawaniem [30]. Dowodzą tego badania kohortowe ze Szwecji [39], ze Szkocji [40] i ze Stanów Zjednoczonych, prowadzone w ramach programu NHANES [41]. 
Mechanizm tego działania nie jest do końca znany, ale podejrzewa się, że jest on związany z syntezą S-adenozylometioniny uczestniczącej w metylacji neurotransmiterów (katecholamin, indoloamin), mieliny i fosfolipidów błon komórkowych w tkance mózgowej [20] lub potencjalną zdolnością homocysteiny do wywoływania chorób naczyniowych, co może skutkować niedotlenieniem mózgu [42].

Homocysteina i jej metabolity poprzez stymulację receptora N-metylo-D-asparaginianu mogą przyczyniać się do toksycznego uszkodzenia neuronów, co z kolei wywołuje nadmierny dopływ jonów wapnia oraz generowanie wolnych rodników w komórce [20]. W doświadczeniach z udziałem szczurów udowodniono, że homocysteina indukuje apoptozę w neuronach hipokampu [43], a w hodowlach komórkowych zwiększa toksyczność miedzi i $\alpha$-amyloidu [44].

\section{Zasadność stosowania suplementacji kwasem foliowym}

Kwas foliowy jest związkiem odgrywającym istotną rolę w prawidłowym działania organizmu człowieka. Dostarczenie zgodnej z zapotrzebowaniem organizmu ilości folianu w diecie jest problematyczne, ponieważ długotrwałe przechowywanie produktów spożywczych, które są ich naturalnym źródłem, oraz ich obróbka technologiczna wpływają negatywnie na ilość i przyswajalność tej witaminy. Kwas foliowy i jego pochodne są wrażliwe na wysoką temperaturę, pH środowiska i promieniowanie UV. W czasie produkcji mąki z ziaren pszenicy utrata wartościowych składników mineralnych, błonnika, witamin i fitozwiązków wynosi nawet do 90\%. Podczas wypieku chleba straty folianów sięgają ok. 30\% i zależą od temperatury i czasu pieczenia [1, 2, 4, 10].

U osób w wieku podeszłym bezpośredni wpływ na spożywanie odpowiednich ilościowo i jakościowo porcji pożywienia mają dodatkowo zmiany zachodzące w przewodzie pokarmowym - począwszy od braków w uzębieniu, upośledzających gryzienie i żucie, poprzez obniżenie zdolności odczuwania smaku, zmniejszenie ilości wydzielanej śliny i zawartych w niej enzymów trawiennych, po możliwe trudności w połykaniu. Z upływem czasu, w żołądku zanikają komórki wydzielające enzymy trawienne, a w jelicie cienkim obniża się efektywność wchłaniania, co może prowadzić do niedoboru wielu witamin, w tym kwasu foliowego. Inne przyczyny deficytów folianów u osób starszych to picie alkoholu, palenie papierosów oraz polipragmazja. Zawarty w napojach alkoholowych etanol dostarcza pustych kalorii, co wpływa na obniżenie apetytu i staje się przyczyną niedożywienia. Nadmierne spożycie alkoholu zaburza też procesy wchłaniania i trawienia składników odżywczych oraz zwiększa ich wydalanie z moczem.
Niedobór kwasu foliowego odnotowuje się u około 80\% uzależnionych z rozpoznaną alkoholową chorobą wątroby. Przyswajalność witaminy $B_{9}$ może być utrudniona przez zażywanie pewnych leków, m.in. leków z grupy antagonistów kwasu foliowego, niesteroidowych leków przeciwzapalnych (np. ibuprofenu, aspiryny), leków działających na kwasowość przewodu pokarmowego (np. preparatów magnezu i glinu) czy leków przeciwgruźliczych [2, 8].

Niedostateczne spożycie kwasu foliowego może być przyczyną wielu omówionych powyżej schorzeń. Jednak w istotny sposób ryzyko wystąpienia zaburzeń stanu zdrowia mogą obniżyć suplementy diety.

Ustawa o warunkach zdrowotnych żywności i żywienia [23] nazywa suplementem diety środek spożywczy, którego celem jest uzupełnienie zwykłej diety. Inaczej suplement określany jest jako skoncentrowane źródło witamin, składników mineralnych oraz innych substancji, które mają działanie odżywcze bądź inne wywierające wpływ na fizjologiczne funkcje organizmu.

Rząd amerykański w 1998 roku wdrożył obowiązek wzbogacania kwasem foliowym mąki i produktów zbożowych [46]. W 1995 roku obowiązkową fortyfikację przyjęto także w Kanadzie, a w 2000 roku w Chile. Na zasadzie dobrowolności procedurę tę w 1995 wprowadzono w Zachodniej Australii. Skuteczność takiej fortyfikacji okazała się wysoka. Znaczny wzrost stężenia kwasu foliowego, a równocześnie obniżenie stężenia homocysteiny we krwi uzyskano w Stanach Zjednoczonych, Kanadzie i Chile. Zarówno w tych krajach, jak i w Zachodniej Australii zaobserwowano 15-20\% obniżenie częstości występowania wad cewy nerwowej (WCN) [29, 47]. Pomimo tak pozytywnych efektów niektóre kraje europejskie (Dania, Finlandia, Szwecja) nie podjęły decyzji o wprowadzeniu obowiązkowej fortyfikacji folianem zbożowych produktów spożywczych [3].

W Stanach Zjednoczonych, gdzie wzbogacanie produktów zbożowych kwasem foliowym jest obligatoryjne, dodatek kwasu foliowego jest równy 0,14 mg/100 g mąki, makaronu i innych zbożowych produktów. Podobnie jest w Wielkiej Brytanii, gdzie dosypuje się 0,24 mg kwasu foliowego na każde $100 \mathrm{~g}$ mąki. W krajach tych zauważono istotny spadek urodzeń noworodków z wadami cewy nerwowej oraz zmniejszenie ilości przypadków udaru niedokrwiennego mózgu u osób starszych [4, 46, 48]. Mąka została wybrana nośnikiem folianów ze względu na stosunkowo niską cenę, częstość wykorzystania w gastronomii oraz możliwość profilaktyki na szeroką skalę. Dodawanie kwasu foliowego w stosunkowo niewielkich ilościach wynika z niepokoju związanego z możliwością zbyt dużego pobrania tej witaminy, co może m.in. owocować u osób starszych maskowaniem objawów niedoboru witaminy $\mathrm{B}_{12}$ [4]. 
W Polsce fortyfikacja żywności kwasem foliowym jest dobrowolna. Z badań Sicińskiej i Pelc [1, 49] wynika, że na rynku polskim obecnych jest ponad 160 produktów fortyfikowanych kwasem foliowym. Grupę największą stanowią produkty zbożowe (mąki pszenne, płatki śniadaniowe), a także napoje, soki, słodycze. Maksymalną ilość dodatku podaje Rozporządzenie Ministra Zdrowia dnia 16 września 2010 r. w sprawie substancji wzbogacających dodawanych do żywności [50]. Z powodu strat, do których dochodzi w toku przygotowywania żywności, dozwolona największa ilość dodawanego kwasu foliowego to nie więcej niż 100\% pożądanego dziennego spożycia na $100 \mathrm{~g}$ lub $100 \mathrm{ml}$ produktu spożywczego.

\section{Podsumowanie}

Analizując powyższe dane można stwierdzić, iż kwas foliowy i foliany należy uznać za ważny składnik odżywczy, który może mieć wpływ na zmniejszenie zapadalności na choroby i umieralność wśród osób starszych [1, 2, 4, 8]. Zmniejszenie ryzyka chorób na tle niedoboru kwasu foliowego jest możliwe przez zwiększenie spożycia produktów spożywczych bogatych w naturalne foliany, spożywanie żywności wzbogacanej w kwas foliowy i przyjmowanie $z$ całodziennym pożywieniem suplementów diety zawierających syntetyczny kwas foliowy [4, 29, 46, 47, 48]. Z punktu widzenia interesów ekonomicznych są to mało kosztowne działania interwencyjne o charakterze prozdrowotnym. Jednocześnie należy także prowadzić działania edukacyjne, ponieważ przy łącznym spożywaniu produktów wzbogaconych i stosowaniu suplementów diety może dojść, w indywidualnych przypadkach, do przekroczenia górnych dopuszczalnych poziomów spożycia folianów [4].

\section{Piśmiennictwo}

1. Cieślik E, Kościej A. Kwas foliowy - występowanie i znaczenie. Probl Hig Epidemiol 2012; 93(1): 1-7.

2. Kapka-Skrzypczak L, Niedźwiecka J, Skrzypczak M, Wojtyła A. Kwas foliowy - skutki niedoboru i zasadność suplementacji. Med Ogólna i Nauki o Zdrowiu 2012; 18 (1): 65-69.

3. Eichholzer M, Tönz O, Zimmermann R. Folic acid: a publichealth challenge. Lancet 2006; 367: 352-361.

4. Czeczot H. Kwas foliowy w fizjologii i patologii. Postępy Hig Med Dośw 2008; 62: 405-419.

5. Reynolds EH. Vitamin B12, folic acid, and the nervous system. Lancet Neurol 2006; 5: 949-960.

6. Stover PJ. Physiology of folate and vitamin B12 in health and disease. Nutr Rev 2004; 62: S3-S12.

7. Tamura T, Picciano MF. Folate and human reproduction. Am. J. Clin. Nutr. 2007; 83: 993-1016.

8. Brzozowska A, Sicińska E, Roszkowski W. Rola folianów w żywieniu osób starszych. ROCZN. PZH 2004; 55 (2): 159-164.

9. Stanger O. Physiology of Folic Acid in Health and Disease. Curr Drug Metab. 2002; 3(2): 211-223.

10. McNulty H, Pentieva K. Folate bioavailability. Proc Nutr Soc. 2004; 63(4): 529-536.
11. Ziemlański Ś, Wartanowicz M. Rola folianów w żywieniu kobiet i dzieci. Pediatr Współcz Gastroenterol Hepatol Żywienie Dziecka. 2001; 3(2): 119-125.

12. Sicińska E, Wyka J. Spożycie folianów w Polsce na podstawie piśmiennictwa z ostatnich 10 lat (2002-2010). ROCZN. PZH 2011; 62 (3): 247-256.

13. Gryszczyńska A. Witaminy z grupy B - naturalne źródła, rola w organizmie, skutki awitaminozy. Post Fitoter 2009; 4: 229-238.

14. Charzewska J, Rogalska-Niedźwiedź M, Wajszczyk B, Chabros E. Chwojnowska Z, Kokosa J. Folate intake in population of young females at reproductive age and in the elderly population. First International Conference on Folates. Analysis, Bioavailability and Health. 11-14 luty 2004, Warszawa: Wyd. SGGW; 179-183.

15. Wierzbicka E, Brzozowska A, Roszkowski W. Energy and nutrientintake of elderly people living in the Warsaw region, Poland. J Nutr Health Aging 2001; 5(4): 248-252.

16. Stawarska A, Tokarz A, Kolczewska M. Ocena ilościowa składników mineralnych i witamin w dietach ludzi starszych zrzeszonych w wybranych warszawskich stowarzyszeniach społecznych. cz. III. Bromat Chem Toksykol 2009; 42 (2): 117-122.

17. Lesser S, Pauly L, Volkert D. Nutritional Situation of the Elderly in Eastern / Baltic and Central/ Western Europe - The AgeingNutrition Project. Ann. Nutr. Metab. 2008; 52: 62-71.

18. Malinowska A, Gawęcki J, Chmurzyńska A. Ocena pokrycia zapotrzebowania na foliany u osób starszych z Wielkopolski. W: Materiały Konferencyjne IX Krajowe Warsztaty Żywieniowe pt: „Niepożądane reakcje pokarmowe i zaburzenia odżywiania", 1-3 września 2010, Szczecin, 41.

19. Piotrowska E. Oszacowanie spożycia folianów na podstawie badań budżetów gospodarstw domowych w latach 2000-2007. Praca magisterska. Warszawa: Wydział Nauk o Żywieniu Człowieka i Konsumpcji SGGW; 2010.

20. Miller AL, Kelly GS. Homocysteine metabolism: nutritional modulation and impact on health and disease. Alt. Med. Rev. 1997; 2: 234-254.

21. Hoogeveen EK, Kostense PJ, Beks PJ, Mackaay AJC, Jakobs C, Bouter LM, Heine RJ, Stehouwer CDA. Hyperhomocysteinemia is associated with an increased risk of cardiovascular disease, especially in non-insulin-dependent diabetes mellitus. A population based study. Arterioscler. Tromb. Vasc. Biol. 1998; 18: 133-138.

22. Palasik W. Homocysteina - czynnik ryzyka występowania niedokrwiennego udaru mózgu. Post. Nauk Med. 2001; 3-4: 45-48.

23. Meleady R, Ueland PM, Blom H, Whitehead AS, Refsum H, Daly LE, Vollset SE, Donohue C, Giesendorf B, Graham IM, Ulvik A, Zhang Y, Monsen A-LB. Thermolabile methylenetetrahydrofolate reductase, homocysteine, and cardiovascular disease risk: the European Concerted Action Project. Am. J. Clin. Nutr. 2003; 77: 63-70.

24. Shelub J, Jacques PF, Wilson PWF, Rush D, Rosenberg IH. Vitamin status and intake as primary determinants of homocysteinemia in an elderly population. JAMA 1993; 270 : 2693-2698.

25. Choi S-W, Mason JB. Folate and carcinogenesis: an integrated scheme. J. Nutr. 2000; 130(2): 129-132.

26. Rampersaud GC, Kauwell GPA, Hutson AD, Cerda JJ, Bailey LB. Genomic DNA methylation decreases in response to moderate folate depletion in elderly women. Am. J. Clin. Nutr. 2000; 72: 998-1003.

27. Crott JW, Choi S-W, Ordovas JM, Ditelberg JS, Mason JB. Effects of dietary folate and aging on gene expression in 
the colonic mucosa of rats: implications for carcinogenesis. Carcinogenesis 2004; 25(1): 69-76.

28. Rampersaud GC, Bailey LB, Kauwell GPA. Relationship of folate to colorectal and cervical cancer: review and recommendation for practitioners. J. Am. Diet. Assoc. 2002; 102: 1273-1282.

29. Kim YI. Will mandatory folic acid fortification prevent or promote cancer? Am J Clin Nutr 2004; 80(5): 1123-1128.

30. Giovannucci E, Stampfer MJ, Colditz GA, Rimm EB, Trichopoulos D, Rosner BA, Speizer FE, Willett WC. Folate, methionine and alcohol intake and risk of colorectal adenoma. J. Natl. Cancer Inst. 1993; 85: 875-884.

31. Giovannucci E, Stampfer MJ, Colditz GA, Hunter DJ, Fuchs C, Rosner BA, Speizer FE, Willett WC. Multivitamin use, folate, and colon cancer in women in the Nurses' Health Study. Ann. Intern. Med. 1998; 129: 517-524.

32. Su LJ, Arab L. Nutritional status of folate and colon cancer risk: Evidence from NHANES I epidemiologic follow-up study. Ann. Intern. Med. 2001; 129: 517-524.

33. Rohan TE, Jain MG, Howe GR. Dietary folate consumption and breast cancer risk. J. Natl. Cancer Inst. 2000; 92: 266-269.

34. Sellers TA, Kushi LH, Cerhan JR, Vierkant RA, Gapstur SM, Vachon CM, Olson JE, Therneau TM, Folsom AR. Dietary folate intake, alcohol, and risk of breast cancer in a prospective study of menopausal women. Epidemiology 2001; 12: 420-428.

35. Zhang S, Humter DJ, Hankinson SE, Giovannucci EL, Rosner BA, Colditz GA, Speizer FE, Willett WC. A prospective study of folate intake and risk of breast cancer. JAMA 1999; 281: 1632-1637.

36. Dufouil C, Alperovitch A, Ducros V, Tzourio C. Homocysteine, white mater hyperintensities, and cognition in healthy elderly people. Ann. Neurol. 2003; 53: 214-221.

37. Teunissen CE, Blom AHJ, van Boxtel MPJ, Bosma $\mathrm{H}$, de Bruijn C, Jolles J, Wauthers BA, Steinbusch WM, Vente J. Homocysteine: a marker for cognitive performance? A longitudinal follow-up study. J. Nutr. Health Aging 2003; 7: 153-159.

38. Snowdon DA, Tully CL, Smith CD, Riley KP, Markesbery WR. Serum folate and the severity of athrophy of neocortex in Alzheimer disease: findings from the Nun Study. Am. J. Clin. Nutr. 2000; 71: 993-998.

39. Wang HX, Wahlin A, Basun H, Fastbom J, Winblad B, Fratiglioni L. Vitamin B12 and folate in relation to the development of Alzheimer's disease. Neurology 2001; 56: 1188-194.

40. Duthie SJ, Whalley LJ, Collins AR, Leaper S, Berger K, Deary IJ. Homocysteine, B vitamins status, and cognitive function in the elderly. Am. J. Clin. Nutr. 2002; 75: 908-913.

41. Morris MS, Jacques PF, Rosenberg IH, Selhub J. Hyperhomocysteinemia associated with poor recall in the third $\mathrm{Na}$ tional Health and Nutritional Examination Survay. Am. J. Clin. Nutr. 2001; 73: 927-933.
42. Selhub J, Bagley LC, Miller J, Rosenberg IH. B vitamins, homocysteine, and neurocognitive function in elderly. Am. J. Clin. Nutr. 2000; 71: 614S-620S.

43. Kruman II, Culmsee C, Chan SL, Kruman Y, Guo Z, Penix L, Mattson MP. Homocysteine elicits a DNA damage response in neurons that promotes apoptosis and hypersensivity to excitotoxicity. J. Neurosci. 2000; 20: 6920-6926.

44. White AR, Hunag X, Jobling MF, Barrow CJ, Beyreuther K Masters CL, Bush Al, Cappai R. Homocysteine potentiates copper- and amyloid beta peptide- mediated toxicity in primary neuronal cultures: possible risk factors in the Alzheimer's-type neurodegenerative pathways. J. Neurochem. 2001; 76: 1509-1520.

45. Obwieszczenie Marszałka Sejmu Rzeczypospolitej Polskie z dnia 7 lutego 2005 r. w sprawie ogłoszenia jednolitego tekstu ustawy o warunkach zdrowotnych żywności i żywienia. Dz.U. 2005, nr 31, poz. 265

46. Brouwer IA, van Dusseldorp M, West CE, Steegers-Theunissen RP. Bioavailability and bioefficacy of folateand folic acid in man. Nutr Res Rev. 2001; 14(2): 267-294.

47. Hertrampf E, Cortés F, Erickson JD, Cayazzo M, Freire W, Bailey LB, et al. Consumption of Folic Acid-Fortified Bread Improves Folate Status in Women of Reproductive Age in Chile. J Nutr. 2003; 133(10): 3166-3169.

48. Kawka A. Przetwory zbożowe - aspekty wzbogacania wartości odżywczej. Prz Zboż-Młyn 2009: 10.

49. Sicińska E, Pelc A. Produkty wzbogacone jako potencjalne źródło kwasu foliowego w żywieniu człowieka. Rocz PZH 2011; 62(2): 209-214.

50. Rozporządzenie Ministra Zdrowia z dnia 16 września 2010 r. w sprawie substancji wzbogacających dodawanych do żywności. Dz.U. z 2010 r. nr 174 poz. 1184.

Artykuł przyjęty do redakcji: 16.07.2016

Artykuł przyjęty do publikacji: 20.08.2016

Źródło finansowania: Praca nie jest finansowana z żadnego źródła. Konflikt interesów: Autorzy deklarują brak konfliktu interesów.

\author{
Adres do korespondencji: \\ Przemysław Domagała \\ ul. Dębinki 7 \\ 80-211 Gdańsk \\ tel.: 583491980 \\ e-mail: coxbrikasta@gumed.edu.pl \\ Zakład Zarządzania w Pielęgniarstwie \\ Gdański Uniwersytet Medyczny
}

